\title{
Impact of Surgical Safety Checklist Training on Nurses' Compliance in Operating Room
}

\author{
$1^{\text {st }} \mathrm{P}$ R Kusumaningrum \\ Nursing Department \\ STIKES Muhammadiyah Klaten \\ J1 Ir Soekarno KM 1 Buntalan 57419 \\ Klaten, Indonesia \\ puput@stikesmukla.ac.id \\ $4^{\text {th }}$ A A Krismiyantara \\ Nursing Department \\ STIKES Muhammadiyah Klaten \\ J1 Ir Soekarno KM 1 Buntalan 57419 \\ Klaten, Indonesia
}

\author{
$2^{\text {nd }}$ Daryani \\ Nursing Department \\ STIKES Muhammadiyah Klaten \\ Jl Ir Soekarno KM 1 Buntalan 57419 \\ Klaten, Indonesia
}

\author{
$3^{\text {rd }}$ F Suciana \\ Nursing Department \\ STIKES Muhammadiyah Klaten \\ J1 Ir Soekarno KM 1 Buntalan 57419 \\ Klaten, Indonesia
}

\begin{abstract}
Surgical Safety Checklist (SSC) is a part of patient safety, which used through 3 stages according to the timeline is before induction of anesthesia (Sign In), before skin incision (Time Out) and before removing the patient from operating room (Sign out). The positive impact of SSC is improving patient safety, improving hospital service quality and reduce the workload of nurses. The purpose of this study was to make an impact of SSC on nurse training in operating room on compliance with SSC filling. This research method use Pre-Experimental with One Group Pre-Post Test Design and with total sampling method of 14 nurses. The results showed that SSC filling training influenced the increase in respondents' compliance with SSC compliance doubled. The results showed that the total value of $p=0.005(\alpha=0.05)$ which means the effect of the surgical safety checklist filling on compliance with the surgical safety checklist before and after the training.
\end{abstract}

Keywords-Surgical Safety, Checklist Training, Nurse

\section{INTRODUCTION}

Patient Safety is also one of the dimensions of quality that is currently become the concern of health care practitioners on a national and global scale. The World Health Organization (WHO) estimates that there are at least half a million deaths from surgery that could have been prevented. The Safe Surgery Saves Lives program introduces and conducts a surgical safety checklist in an effort to save patients and reduce the number of deaths worldwide. The main purpose of the surgical safety checklist is to reduce unexpected events (KTD) in the surgery room [1], [2].

WHO (2008) explains that the surgical safety checklist in the surgery room is used in 3 stages, each in accordance with the timeline as before induction of anesthesia (Sign In), before a skin incision (Time Out) and before removing the patient from the operating room (Sign out). The Surgical Safety Checklist is a standard from WHO which is a practical and simple communication tool in ensuring patient safety in the preoperative, intraoperative and postoperative stages [3].

The low application of Surgical Safety Checklist at Hospital IBS (Central Surgical Installation) is risking the misplaced incidents, wrong procedures, wrong patients on surgery. KTD that occurs in surgery can have a detrimental effect on the patient, increase the number of morbidity and length of patient care, besides that it can cause the decrease of the hospital quality. The other impact is that it causes public confidence in hospitals to decline. Cases related to surgery in Indonesia include gauze left in the space between the muscles and bones and foot amputation [4].

The aim of the checklist was to ensure that important details of the case were not missed, to serve as a tool to encourage teamwork and to improve communication among operating room staff. Since its introduction, the surgical safety checklist has been implemented in the operating room of more than 4,000 hospitals. Studies have shown a decrease in both operating room morbidity and mortality as well as an improvement in communication, team behaviors, and attitudes in the operating room [5], [6].

Siagian (2011) in the case of digestive surgery at the Central Surgical Installation Dr. Sardjito in Yogyakarta, found the implementation of Surgical Safety Checklist has not been consistently carried out, with the discovery of unexpected events including surgical wound infection $(9.1 \%)$, coma $>24$ hours $(2.3 \%)$, use of ventilators $>48$ hours $(4.5 \%)$, unplanned re-surgery of patients $(2.3 \%)$, bleeding requiring transfusion within 72 hours $(4.5 \%)$ and death (4.5\%). From these results the hospital needs to carry out surgical patient safety routinely and continuously to determine its effect on the quality of patient care [1].

Compliance in performing Surgical Safety is an action to perform surgical safety correctly and properly. The WHO checklist has been designed efficiently and effectively to be used by the surgical team in the operating room, so that additional periodic knowledge and socialization are needed for operating room personnel to increase their knowledge, acceptance, and ability to apply [7].

Efforts are being made to tackle KTD by increasing nurses' knowledge through workshops, seminars, training and education. The training that nurses must have at IBS 
is Basic Surgery Training. Basic Surgery Training includes peri operative care in the operating room, job desciption for the operating room nurse, operating area incision, surgical instruments, sterilization, aseptic area of the surgery, drapping, principles of sterile technique and patient safety in the operating room [8]. The purpose of this study was to determine the effect of surgical safety checklist training on nurse compliance in operating room.

\section{METHODS}

This study used a Pre Experimental design with One Group Pre Test-Post Test Design, where in this study there were no control or comparison groups but the first observation was made (pre-test) that allowed researchers to test changes that occurred after the experiment. This study involved 14 nurses. Sampling in this study was conducted by the total sampling method. Criteria for exclusion of the sample is not attending the training until completion.

In this study a preliminary measurement (pre-test) of adherence to respondents using the compliance questionnaire filled with surgical safety checklist in the operating room by Efa Trisna (2016) with a total of 20 questions. Provision of action or intervention in the form of training in filling the surgical safety checklist conducted after work for one day. After completing the surgical safety checklist, observations were made for 7 days on the surgical safety checklist filled in by 14 respondents while working. The Wilcoxon test is used as a data analysis method for interventions before and after training is given.

\section{RESULTS}

Nurses who were the subjects in this study averaged 37.92 years of age, $57.1 \%$ of the subjects were male and $92.9 \%$ were educated in Nursing Diploma III (table 1).

TABLE 1. SUBJECT CHARACTERISTICS
\begin{tabular}{|l|c|c|}
\hline \multicolumn{1}{|c|}{ Variabel } & F & Number \\
\hline Gender & 8 & 57,1 \\
Male & 6 & 42,9 \\
Female & & \\
Education & 13 & 92,9 \\
DIII Nursing & 1 & 7,1 \\
DIV Nursing & & \\
\hline
\end{tabular}

Compliance before being given training showed that there were 8 people who disobey $(57.1 \%)$ and after being given training it becomes $100 \%$ obedient (tabel 2).

The Wilcoxon test shows the effect of surgical safety checklist training on nurse compliance in operating room with a $p$ value $=0.005(\alpha=0.05)($ tabel 3$)$.

\begin{tabular}{|c|c|c|c|c|}
\hline \multirow[t]{2}{*}{ Compliance } & Pre & & Post & \\
\hline & $\mathrm{F}$ & Number & $\mathrm{f}$ & Number \\
\hline Yes & 6 & 42,9 & 14 & 100 \\
\hline No & 8 & 57,1 & 0 & 0 \\
\hline
\end{tabular}

TABLE 3. EFFECTS OF TRAINING ON COMPLIANCE WITH THE SURGICAL SAFETY CHECKLIST

\begin{tabular}{|l|c|c|}
\hline Group & $\mathrm{Z}$ & $\mathrm{P}$ \\
\hline Pretest - Postest & $-2,826$ & 0,005 \\
\hline
\end{tabular}

\section{DISCUSSIONS}

Surgical safety checklist is a communication tool for patient safety that is used by the surgical team in the operating room. The surgical team consists of nurses, surgeons, anesthesiologists and others. The surgical team must consistently perform every item performed in the surgery starting from sign in, time out, sign out so as to minimize any unwanted risks [9], [10].

Surgical safety checklist is an effort to maintain patient safety in the operating room, which is implementing the Standard Operational Procedure (SOP) in every nurse's action, using the surgical safety checklist form. Patient safety aims to improve services and avoid malpractice demands. The main purpose of the surgical safety checklist is to reduce KTD in the operating room [1], [11]. The positive impact of the Surgical Safety Checklist is to improve patient safety, improve the quality of hospital services and reduce the workload of nurses [12]. Patient safety, especially during the surgical process is also regulated by WHO in the WHO Guidelines for Safe Surgery 2009. Safety surgery is a patient safety step in the operating room to improve patient safety during surgical procedures, prevent operation site errors, and reduce complications of death due to surgery [13]. The low application of Surgical Safety Checklist at Hospital IBS (Central Surgical Installation) is risking the misplaced incidents, wrong procedures, wrong patients on surgery. KTD that occurs in surgery can have a detrimental effect on the patient, increase the number of morbidity and length of patient care, besides that it can cause the decrease of the hospital quality. The other impact is that it causes public confidence in hospitals to decline. Cases related to surgery in Indonesia include gauze left in the space between the muscles and bones and foot amputation [4], [14]. Efforts are being made to tackle KTD by increasing nurses' knowledge through workshops, seminars, training and education. The training that nurses must have at IBS is Basic Surgery Training. Basic Surgery Training includes peri operative care in the operating room, job desciption for the operating room nurse, operating area incision, surgical instruments, sterilization, aseptic area of the surgery, drapping, principles of sterile technique and patient safety in the operating room [8].

Training is a process that emphasizes more on practice than theory carried out by someone who works or a group of work units using an adult learning approach (andragogy) that aims to improve working ability and skills. According to Gary Dessler (1997: 263) in Aditya (2013), argues that training is the process of teaching new employees about the basic skills they need to carry out their work [15].

The training aims to increase productivity, improve quality, support HR planning, improve member morale, 
provide indirect compensation, improve occupational health and safety, prevent expired skills and knowledge of personnel, improve the development of personnel capabilities and expertise [16]. Lack of knowledge about the surgical safety checklist causes low compliance with the implementation of surgical safety checklist and low completeness in filling the form [17]. Compliance is a behavior in the form of a response or reaction to a stimulus or stimulation from outside the individual. In giving a response, it really depends on the characteristics or other factors. Green (1980) in Notoatmojo (2012) explained that a person's behavior is influenced by three factors: predisposing factors, supporting factors, and driving factors. Perception is included in the predisposing factor, a person's perception will have an impact on compliance in doing something [4].

In this study, the training in filling the Surgical Safety Checklist was given to add respondents' information and insights so that respondents' knowledge increased about how to fill in and apply surgical safety checklist in each surgical process according to the procedure. Respondents' perceptions or responses about the importance of the Surgical Safety Checklist can increase respondents' compliance in completing the Surgical Safety Checklist in accordance with the SOP. Based on the results of the study after being given training, $100 \%$ of nurses adhere to completing the Surgical Safety Checklist perfectly, all filling the Surgical Safety Checklist properly.

\section{CONCLUSION}

Based on the explanation above, it can be concluded that there is a significant difference in compliance with filling SSC in the operating room after being given a training of filling Surgical Safety Checklist form.

\section{REFERENCES}

[1] E. Siagian, "Pelaksanaan Surgical Patient Safety Terhadap Adverse Events Pascaoperasi Bedah Digesti di Instalasi Bedah RSUP Dr. Sardjito Yogyakarta,” 2011.

[2] et al Haynes AB, Weiser TG, Berry WR, Lipsitz SR, Breizat AH, Dellinger EP, "A Surgical Safety Checklist to Reduce Morbility and Mortality in Global Population," N Engl J Med, 2019.

[3] WHO, "Forward Programme 2008-2009," 2009.

[4] E. Trisna, "Hubungan Persepsi Tim Bedah Dengan Kepatuhan Penerapan Surgical Patient Safety Pada Pasien Operasi Bedah Rumah Sakit Umum Daerah Mayjend HM. Ryacudu," J. Kesehat., vol. VII, pp. 341-344, 2016.

[5] et al Cabral RA, "Use of The Surgical Safety Checklist to Improve Team Communication," AORN J, pp. 104:206-216, 2016.

[6] et al Pugel AE, "Use of the Surgical Safety Checklist to Improve Communication and Reduce Complications," J Infect Public Heal., pp. 8:219-225, 2015.

[7] Y.-H. Wangoo, L., Ray, R. A., \& Ho, "Compliance and Surgical Team Perceptions of WHO Surgical Safety Checklist; Systematic Review. International Surgery,” 2016.

[8] HIPKABI, Buku Pelatihan Dasar-Dasar Keterampilan bagi Perawat K amar Bedah. Jakarta: HIPKABIi Pres, 2014.

[9] Suatmadji., Surgical Safety Checklist Dikamar Bedah.Seminar HIPKABI. Padang. 2015.

[10] G. M. Melekie, T. B., \& Getahun, "Compliance with Surgical Safety Checklist completion in the operating room of University of Gondar Hospital, Northwest Ethiopia," BMC Res. Notes, no. 8(1), 361, 2015.
[11] J. C. I. (JCI), Patient Safety, essentials for health care. (International Edition), Internatio. USA, 2011.

[12] et al. Mayer sevdaliist, "Surgical Checklist Implementation Project: The Impact of Variable WHO Checklist Compliance on Risk-adjusted Clinical Outcomes After National Implementation," 2015.

[13] WHO, "Surgical Safety Check List Reinforces Accepted safety Practices and Foster Better Commnication and Teamwork.," 2009.

[14] A. Cavoukian, "The Surgical Safety Checklist: A Must for Hospitals Performing Surgery," 2009.

[15] Aditya Ramdhani, "Pelaksanaan Program Pelatihan dan Kompetensi Pengaruhnya terhadap Kinerja Karyawan di PT. Otto Phrmaceutical Industries," 2013.

[16] W. S. Eko, Manajemen Pengembangan Sumber Daya Manusia. Yogyakarta: PUSTAKA PELAJAR, 2015.

[17] J. Sandrawati and S. Supriyanto, "SURGICAL SAFETY CHECKLIST DI KAMAR BEDAH ( Recommendations to Improve the Implementation Compliance of Surgical Safety Checklist in Surgery Rooms )," pp. 71-79, 2013. 